\title{
PERBEDAAN FAKTOR RISIKO DAN PERILAKU DETEKSI DINI KANKER SERVIKS PADA WANITA USIA SUBUR ANTARA WILAYAH PARUNGKUDA DENGAN PALABUHANRATU
}

\author{
Vini Yuliani'1), Johanes C. Mose'2), Herman Susanto ${ }^{3)}$ \\ 1Dosen Prodi D III Kebidanan Stikes Sukabumi \\ 2,3Departemen Obstetri dan Ginekologi Fakultas Kedokteran Universitas Padjadjaran \\ email: vinny.jeroline06@gmail.com
}

\begin{abstract}
BackgroundOne of the causes the high mortality rate due to cervical cancer is late detection and admission to the hospital in stages IIB-IVB which are advanced. Delayed early detection is caused by low awareness of the community to undergo VIA test and it is influenced by perceptions arise. Currently in Sukabumi district there is still a phenomenon of increasing incidence of cervical cancer and low early detection behavior. Based on data from Sukabumi District Health Office, the highest prevalence of cervical cancer incidence is in urban area, while coastal area is low.

Purpose :Analyze the differences of risk factors and the behavior of early detection of cervical cancer in Women Aged Fertile (WUS) between the working area of Puskesmas Parungkuda and Palabuhanratu.

Methods:This study used a comparative analytic study design with cross sectional approach, sample size was 120 WUS in Parungkuda and Palabuhanratu. Data were analyzed using Chi-square for categorical data and Mann-Witney test for interval data.

Results :showed that there were differences of cervical cancer risk factors between the working area of Puskesmas Parungkuda and Palabuhanratu, age of first sexual intercourse $(p=0,008)$, parity $(p=0,239)$, pill contraception $(p=0,002)$, number of sexual partner $(p=0.040)$, and there are behavioral differences (HBM) early detection of cervical cancer, susceptibility variable $(p=0,026)$, severity variable $(p=0,211)$, threat variable $(p=0,416)$, benefit variable $(p=0,895)$, variable of obstacle, $(p=0.672)$ and cues for action $(p<0.001)$. The Conclusion: this research is there are difference of cervical cancer risk factor that is first age having sexual intercourse, pill contraception, parity, and there are difference of behavior (HBM) early detection of cervical cancer that is variable susceptibility and signal to act.
\end{abstract}

Keywords: cervical cancer, VIA, risk factor, early detection behavior, perception.

\section{ABSTRAK}

Latar Belakang:Tingginya angka kematian akibat kanker serviks salah satu penyebabnya keterlambatan deteksi dini dan datang ke rumah sakit pada stadium lanjut, yaitu stadium IIB-IVB. Keterlambatan deteksi dini disebabkan oleh rendahnya kesadaran masyarakat untuk menjalani tes IVA dan hal tersebut dipengaruhi oleh persepsi yang timbul. Saat ini di Kabupaten Sukabumi masih terdapat fenomena meningkatnya kejadian kanker serviks dan rendahnya perilaku deteksi dini. Berdasarkan data dari Dinas Kesehatan Kabupaten Sukabumi didapatkan prevalensi kejadian kanker serviks yang paling tinggi di satu wilayah yang merupakan wilayah perkotaan, sedangkan di wilayah pesisir kejadiannya rendah.

Tujuan: Penelitian ini untuk menganalisis perbedaan faktor risiko dan perilaku deteksi dini kanker serviks pada Wanita Usia Subur (WUS) antara wilayah kerja Puskesmas Parungkuda dengan Palabuhanratu.

Metode:Penelitian ini menggunakan rancangan bersifat studi analitik komparatif dengan pendekatan cross sectional, dengan ukuran sampel sebanyak 120 orang WUS di Parungkuda dan Palabuhanratu. Data dianalisis menggunakan Chi-square untuk data kategorik dan uji Mann-Whitney untuk data berbentuk interval.

Hasil: Terdapat perbedaan faktor risiko kanker serviks antara wilayah kerja Puskesmas Parungkuda dengan Palabuhanratu, usia pertama kali berhubungan seksual $(p=0,008)$, paritas $(p=0,239)$, kontrasepsi pil $(p=0,002)$, jumlah pasangan seksual $(p=0,040)$, dan terdapat perbedaan perilaku (HBM) deteksi dini kanker serviks, variabel kerentanan $(p=0,026)$, variabel keparahan $(p=0,211)$, variabel ancaman $(p=0,416)$, variabel manfaat $(p=0,895)$, variabel hambatan, $(p=0,672)$ serta isyarat untuk bertindak $(p<0,001)$. 
Simpulan: Terdapat perbedaan faktor risiko kanker serviks yaitu usia pertama kali berhubungan seksual, kontrasepsi pil, paritas, dan terdapat perbedaan perilaku (HBM) deteksi dini kanker serviks yaitu variabel kerentanan dan isyarat untuk bertindak.

Kata Kunci: kanker serviks, IVA, faktor risiko, perilaku deteksi dini, persepsi.

\section{PENDAHULUAN}

Berdasarkan data Global Burden Of Cancer (Globocan) dalam International Agency for Research on Cancer (IARC), diketahui bahwa pada tahun 2012 sebanyak 8.201 .575 orang meninggal akibat kanker (Kemenkes RI Pusdatin, 2015), dan menurut World Health Organization (WHO) penyakit kanker merupakan penyebab kematian nomor 2 di dunia sebesar 13\% setelah penyakit kardiovaskular. Kanker juga menjadi salah satu penyakit yang mengancam di Indonesia. Hal ini terlihat dari hasil Riset Kesehatan Dasar 2013 di mana prevalensi kanker di Indonesia mencapai 1,4 per 1000 penduduk dan menduduki posisi ke tujuh sebagai penyakit penyebab kematian.(Kemenkes RI Panduan, 2015)

Pada tahun 2012 ditemukan 527.624 kasus baru di seluruh dunia, dan sebanyak 265.653 meninggal akibat kanker serviks. Jumlah kasus baru kanker serviks di Asia Tenggara mencapai 175.229 kasus dan 94.294 orang meninggal selama tahun 2012.(Ferlay $\mathrm{J}$ et al, 2015) Kanker serviks merupakan penyakit kanker dengan prevalensi tertinggi di Indonesia pada tahun 2013 sebesar $0,8 \%$ atau diperkirakan sebanyak 98.692 kasus. Prevalensi kejadian untuk Provinsi Jawa Barat pada tahun 2013 sebesar 0,7\% atau diperkirakan sebanyak 15.635 kasus. (Kemenkes RI Pusdatin, 2015; Kemenkes RI Panduan, 2015)

Berdasarkan hasil studi pendahuluan yang dilakukan di Kantor Dinas Kesehatan Kabupaten Sukabumi Bidang Pengendalian Penyakit Tidak Menular dan seluruh Rumah Sakit di Kabupaten Sukabumi didapatkan prevalensi kejadian kanker serviks di Kabupaten Sukabumi sebesar 0,6\% dari populasi WUS sebesar 354.470 orang yaitu sebanyak 221 kasus yang tersebar tidak merata. Terdapat 1 wilayah dengan prevalensi tertinggi sebesar 2,6\% dengan 29 kasus yaitu pada wilayah kerja Puskesmas Parungkuda yang hampir seluruhnya terdeteksi pada stadium lanjut yaitu stadium IIB sampai IIIB dan hanya sebagian kecil yang berada pada stadium IIA, namun di wilayah kerja Puskesmas Palabuhanratu prevalensinya rendah bahkan tidak terdapat kejadian sama sekali. (Dinkes Kabupaten Sukabumi, 2017)

Studi epidemiologi menunjukkan 90-95\% kanker serviks berkaitan dengan infeksi Human
Papilloma Virus (HPV) yang ditularkan melalui hubungan seksual.(Maine D, Hurlburt S, Greeson D, 2011) Ada beberapa faktor risiko yang diperkirakan berhubungan dengan kanker serviks, di antaranya menurut penelitian Dwi Faqihatus Syarifah Has dan Lucia Yovita Hendrati bahwa karakteristik responden yang berisiko terhadap kejadian kanker serviks adalah umur, pendidikan, pekerjaan dan pendapatan.( Has DFS dan Hendrati LY, 2009) Faktor risiko medis dan reproduksi yaitu aktivitas seksual pada usia sangat muda, bergantiganti pasangan (multiple sexual partners), jarak kehamilan pendek, paritas tinggi. Beberapa faktor risiko lain dikenal seperti status sosio-ekonomi yang rendah, pengguna pil kontrasepsi, perokok, dan pola makan kekurangan vitamin $\mathrm{A}$ dan $\mathrm{C}$.(Emilia $\mathrm{O}$, Kusumanto A, Freitag H, 2010; Boyle P, Levin B, 2008)

Kanker serviks mudah dicegah jika terdeteksi lebih cepat. Prosedur penyaringan yang paling banyak direkomendasikan di seluruh dunia adalah apusan Papanicolaou (Pap Smear), inspeksi visual serviks dengan asam asetat (VIA), tes DNA HPV dan Kolposkopi.(National Programme For Prevention and Control of Cancer, Diabetes, Cardiovascular Disease and Stroke) Ada beberapa faktor yang dapat mempengaruhi perilaku seseorang. Faktor eksternal dan internal dapat mempengaruhi perilaku WUS untuk menjalani pencegahan kanker serviks terutama dalam deteksi dini. Menurut teori Health Belief Model (HBM) individu akan terlibat dalam perilaku kesehatan preventif jika mereka percaya diri terancam oleh penyakit atau kondisi dan percaya bahwa manfaat dari mengambil tindakan preventif lebih besar daripada hambatan atau biaya tindakan tersebut. Teori HBM juga merupakan konsep utama dalam mengambil tindakan untuk melakukan pencegahan penyakit, sehingga sesuai dengan tindakan untuk melakukan pencegahan terhadap kanker serviks melalui perilaku deteksi dini kanker serviks dengan tes IVA. Dalam studi sebelumnya. Hill, Gardner, dan Rassaby melaporkan bahwa HBM mampu memprediksi $32 \%$ dari variasi dalam niat untuk melakukan deteksi dini Pap Smear.Bensley RJ, Fisher JB, 2009)

Berdasarkan penelitian Guvenc et al menyimpulkan bahwa Skala HBM untuk Kanker 
Serviks dan Tes Pap Smear ditemukan sebagai alat yang valid dan dapat diandalkan dalam menilai keyakinan kesehatan wanita, sehingga dapat mengembangkan program skrining kanker serviks yang lebih efektif.(Guvenc G, Akyuz A, Acikel HC, 2011) Adanya perbedaan tempat tinggal yaitu antara wilayah perkotaan dengan pedesaan diduga berkaitan dengan kejadian kanker serviks, maka dari itu perlu dilakukan penelitian untuk mengetahui perbedaan faktor risiko dan perilaku deteksi dini kanker serviks pada wanita usia subur (WUS) antara wilayah kerja Puskesmas Parungkuda dengan Palabuhanratu.

\section{METODOLOGI PENELITIAN}

Penelitian ini menggunakan rancangan bersifat analitik komparatif studi dengan pendekatan cross sectional, dilakukan di 2 wilayah yaitu wilayah kerja Puskesmas Parungkuda dan Palabuhanratu Kabupaten Sukabumi. Adapun populasi dalam penelitian ini adalah seluruh WUS yang berada di wilayah Parungkuda dan wilayah Pelabuhan Ratu, sampel dalam penelitian ini sebanyak 120 orang WUS dari kedua wilayah dengan teknik pengambilan sampel menggunakan multistage random sampling.(Dahlan S, 2013;
Satari M, Wirakusumah FF, 2010) Jenis data yang digunakan dalam penelitian ini adalah data primer. Untuk sumber data primer adalah data yang diperoleh langsung dari responden. Instrumen pengumpulan data menggunakan kuesioner.

Kuesioner dalam penelitian ini diadopsi dari kuesioner yang digunakan oleh Subdit Kanker pada assassment faktor risiko kanker serviks \& payudara tahun 2010 dan dimodifikasi sesuai kebutuhan peneliti.(Dirjen PP\&PL, 2010) Untuk variabel perilaku digunakan pertanyaan terstruktur berdasarkan dari sintesis teori yang diambil dari tinjauan pustaka teori Health Belief Model yang selanjutnya dari masing-masing variabel dijabarkan, kuesioner perilaku diambil dari penelitian Wigati PW yang telah teruji validitas dan reliabilitasnya. Analisis data yang digunakan adalah analisis univariabel dan bivariabel,(Satari M, Wirakusumah FF, 2010) analisis data bivariabel menggunakan Chi-square untuk data kategorik dan uji MannWitney untuk data berbentuk interval.(Dahlan S, 2013)

\section{HASIL DAN PEMBAHASAN}

Distribusi Karakteristik dari subjek penelitian didapatkan dari 120 responden yang diteliti.

Tabel 1 Distribusi Frekuensi Karakteristik Responden di Wilayah Kerja Puskesmas Parungkuda dan Palabuhanratu

\begin{tabular}{lcccc}
\hline & \multicolumn{5}{c}{ Puskesmas } \\
\cline { 2 - 5 } & $\begin{array}{c}\text { Parungkuda } \\
(\mathrm{n}=60)\end{array}$ & $\%$ & $\begin{array}{c}\text { Pelabuhanratu } \\
(\mathrm{n}=60)\end{array}$ & $\%$ \\
\hline Usia (tahun) & 22 & 36,7 & 18 & 30 \\
$20-30$ & 19 & 31,7 & 23 & 38,3 \\
$31-40$ & 19 & 31,7 & 19 & 31,7 \\
$41-49$ & & & & \\
\hline Pendidikan & 7 & 11,7 & 30 & 50 \\
SD & 28 & 46,7 & 9 & 15 \\
SMP & 16 & 26,7 & 17 & 28,3 \\
SMA & 9 & 15 & 4 & 6,7 \\
Ak/PT & 52 & 86,7 & 52 & 86,7 \\
\hline Pekerjaan & 4 & 6,7 & 3 & 5 \\
Tidak bekerja & 4 & 6,7 & 5 & 8,3 \\
Bekerja sektor formal & & & & \\
Bekerja sektor informal & 25 & 41,7 & 43 & 71.7 \\
\hline Pendapatan keluarga & 35 & 58,3 & 17 & 28,3 \\
< UMR & & &
\end{tabular}

Dari tabel 1, menunjukkan bahwa umur responden dengan persentase terbanyak di Puskesmas Parungkuda 36,7\% (22 orang) berumur 21-30 tahun dan di Puskesmas Palabuhanratu $38,3 \%$ (23 orang) berumur $31-40$ tahun, pendidikan responden dengan persentase terbanyak di Puskesmas Parungkuda 46,7\% (28 orang) adalah tamat SMP dan di Puskesmas Palabuhanratu 50\% (30 orang) adalah tamat SD, Pekerjaan responden persentase terbanyak $86,7 \%$ (52 orang) adalah 
Tidak bekerja baik di Puskesmas Parungkuda maupun Puskesmas Palabuhanratu, dan Pendapatan keluarga pada responden dengan persentase terbanyak di Puskesmas Parungkuda adalah $\geq$ UMR $58,3 \%$ (35 orang) dan di Puskesmas Palabuhanratu presentase terbanyak $71,7 \%$ (43 orang).

Tabel 2 Perbedaan Faktor Risiko Antara Wilayah Kerja Puskesmas Parungkuda dan Palabuhanratu

\begin{tabular}{|c|c|c|c|c|c|}
\hline \multirow[b]{2}{*}{ Faktor Risiko } & \multicolumn{4}{|c|}{ Puskesmas } & \multirow[b]{2}{*}{ Nilai $\left.p^{*}\right)$} \\
\hline & $\begin{array}{l}\text { Parungkuda } \\
(\mathrm{n}=60)\end{array}$ & $\%$ & $\begin{array}{l}\text { Pelabuhanratu } \\
(n=60)\end{array}$ & $\%$ & \\
\hline $\begin{array}{l}\text { Usia berhubungan seksual pertama kali } \\
\leq 16 \\
>16\end{array}$ & $\begin{array}{l}7 \\
53\end{array}$ & $\begin{array}{l}11,7 \\
88,3\end{array}$ & $\begin{array}{l}19 \\
41\end{array}$ & $\begin{array}{l}31,7 \\
68,3\end{array}$ & 0,008 \\
\hline $\begin{array}{l}\text { Paritas } \\
\leq 3 \\
>3\end{array}$ & $\begin{array}{l}44 \\
16\end{array}$ & $\begin{array}{l}73,3 \\
26,7\end{array}$ & $\begin{array}{l}38 \\
22\end{array}$ & $\begin{array}{l}63,3 \\
36,7\end{array}$ & 0,239 \\
\hline $\begin{array}{l}\text { Kontrasepsi pil } \\
\text { Belum pernah } \\
\text { Pil > } 4 \text { tahun }\end{array}$ & $\begin{array}{l}37 \\
23\end{array}$ & $\begin{array}{l}61,7 \\
38,3\end{array}$ & $\begin{array}{c}52 \\
8\end{array}$ & $\begin{array}{l}86,7 \\
13,3\end{array}$ & 0,002 \\
\hline $\begin{array}{l}\text { Jumlah pasangan } \\
1 \\
>1\end{array}$ & $\begin{array}{c}57 \\
3\end{array}$ & $\begin{array}{c}95 \\
5\end{array}$ & $\begin{array}{l}50 \\
10\end{array}$ & $\begin{array}{l}73,3 \\
26,7\end{array}$ & 0,040 \\
\hline
\end{tabular}

Keterangan : *) berdasarkan uji Chi-kuadrat.

Pada tabel 2 Perbedaan faktor risiko dan perilaku deteksi dini kanker serviks antara wilayah kerja puskesmas Parungkuda dengan Palabuhanratu menunjukkan persentase terbanyak untuk faktor risiko usia berhubungan seksual pertama kali antara Wilayah kerja Puskesmas Parungkuda dengan Palabuhanratu yaitu pada umur $>16$ tahun, masing-masing $88,3 \%$ pada WUS di Puskesmas Parungkuda dan $68,3 \%$ pada WUS di Puskesmas Palabuhanratu. Hal ini menunjukkan bahwa sebagian besar responden menjalin hubungan seks pada rentang usia yang aman. Persentase terbesar untuk faktor risiko paritas antara wilayah kerja Puskesmas Parungkuda dengan Palabuhanratu adalah paritas $\leq 3$, masingmasing $73,3 \%$ pada WUS di Puskesmas Parungkuda dan $63,3 \%$ pada WUS di Puskesmas Palabuhanratu. Hal ini menunjukkan bahwa sebagian besar responden tidak berisiko terhadap kanker serviks.

Wanita usia subur antara wilayah kerja Puskesmas Parungkuda dengan Palabuhanratu sebagian besar belum pernah menggunakan kontrasepsi pil dalam jangka waktu $>4$ tahun, masing-masing $61,7 \%$ pada WUS di Puskesmas
Parungkuda dan $86,7 \%$ pada WUS di Puskesmas Palabuhanratu. Wanita usia subur di kedua tempat sebagian besar menggunakan kontrasepsi selain pil. Sebagian besar WUS memiliki jumlah pasangan 1 orang, masing-masing 95\% pada WUS di Puskesmas Parungkuda dan $83,3 \%$ pada WUS di Puskesmas Palabuhanratu. Hal ini menunjukkan bahwa wanita usia subur di kedua daerah setia terhadap pasangan. Hasil analisis uji beda faktor risiko WUS antara wilayah kerja Puskesmas Parungkuda dengan Palabuhanratu menunjukkan bahwa usia berhubungan pertama kali, penggunaan kontrasepsi pil dan jumlah pasangan seksual berbeda secara bermakna $(p<0,05)$.

Tabel 3 dibawah menunjukkan bahwa perilaku penggunaan skrining IVA yang berbeda secara bermakna $(p<0,05)$ yaitu pada variabel WUS mengerti pentingnya skrinning IVA, akan segera melakukan skrinning IVA dan sudah melakukan skrinning IVA sesuai anjuran. Hal ini menunjukkan bahwa perilaku penggunaan skrinning IVA jauh lebih tinggi di Wilayah kerja Puskesmas Parungkuda dibandingkan dengan Wilayah kerja Puskesmas Palabuhanratu. 
Tabel 3 Perbedaan Perilaku Penggunaan Skrining IVA antara Wilayah Kerja Puskesmas Parungkuda dan Palabuhanratu

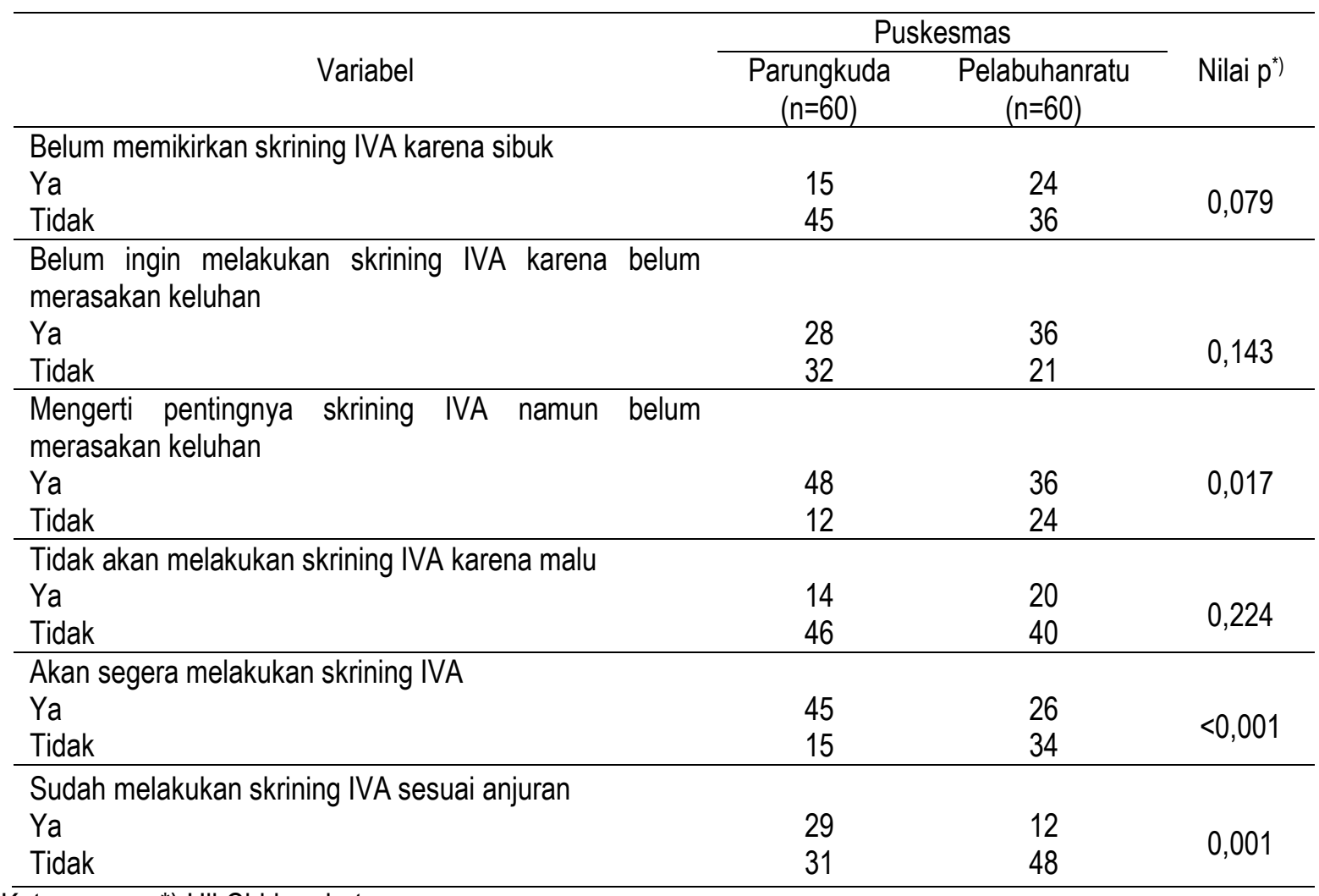

Keterangan : *) Uji Chi-kuadrat

Tabel 4 Perbedaan Perilaku (HBM) Deteksi Dini Kanker serviks antara Wilayah Kerja Puskesmas Parungkuda dan Palabuhanratu

\begin{tabular}{|c|c|c|c|}
\hline \multirow[b]{2}{*}{ Variabel } & \multicolumn{2}{|c|}{ Puskesmas } & \multirow[b]{2}{*}{ Nilai $p^{*}$} \\
\hline & $\begin{array}{l}\text { Parungkuda } \\
(n=60)\end{array}$ & $\begin{array}{l}\text { Pelabuhanratu } \\
(\mathrm{n}=60)\end{array}$ & \\
\hline \multicolumn{4}{|l|}{ Kerentanan : } \\
\hline Rata-rata (SD) & $37,9(17,7)$ & $30,6(18,3)$ & \multirow{3}{*}{0,026} \\
\hline Median & 33,3 & 26,2 & \\
\hline Rentang & $9,5-85,7$ & $0,0-81,0$ & \\
\hline \multicolumn{4}{|l|}{ Keparahan : } \\
\hline Rata-rata (SD) & $56,7(10,0)$ & $53,6(14,3)$ & \multirow{3}{*}{0,211} \\
\hline Median & 57,1 & 52,4 & \\
\hline Rentang & $38,1-76,2$ & $0,0-85,7$ & \\
\hline \multicolumn{4}{|l|}{ Ancaman: } \\
\hline Rata-rata (SD) & $50,6(15,2)$ & $47,7(15,3)$ & \multirow{3}{*}{0,416} \\
\hline Median & 52,4 & 47,6 & \\
\hline Rentang & $23,8-90,5$ & $14,3-90,5$ & \\
\hline \multicolumn{4}{|l|}{ Manfaat: } \\
\hline Rata-rata (SD) & $68,7(13,3)$ & $68,7(14,4)$ & \multirow{3}{*}{0,895} \\
\hline Median & 66,7 & 66,7 & \\
\hline Rentang & $42,9-100,0$ & $42,9-100,0$ & \\
\hline \multicolumn{4}{|l|}{ Hambatan : } \\
\hline Rata-rata (SD) & $43,5(15,1)$ & $43,7(14,9)$ & \multirow{3}{*}{0,672} \\
\hline Median & 42,8 & 42,9 & \\
\hline Rentang & $0,0-100,0$ & $0,0-41,4$ & \\
\hline
\end{tabular}




\begin{tabular}{lccc}
\hline Isyarat bertindak: & & & \\
Rata-rata (SD) & $55,9(11,1)$ & $43,9(14,8)$ & $<0,001$ \\
Median & 52,4 & 42,9 & \\
Rentang & $28,6-85,7$ & $9,5-71,4$ & \\
\hline Gabungan Perilaku (Health Belief Model): & $51,9(7,0)$ & $47,7(7,6)$ & \\
Rata-rata (SD) & 50,5 & 47,8 & 0,001 \\
Median & $38,4-75,9$ & $37,1-68,4$ & \\
Rentang & & &
\end{tabular}

Keterangan : *) Uji Mann-Whitney.

Pada tabel 4, perbedaan perilaku deteksi dini kanker serviks dengan IVA berdasarkan teori HBM menunjukkan bahwa dari 6 variabel Health belief model terdapat 2 varibel perilaku HBM dalam deteksi dini kanker serviks antara wilayah kerja Puskesmas Parungkuda dengan Palabuhanratu yang berbeda secara bermakna $(p<0,05)$ yaitu variabel Persepsi Kerentanan dan Isyarat untuk bertindak. Untuk gabungan perilaku HBM berbeda secara bermakna $(p<0,05)$ antara Puskesmas Parungkuda dengan Puskesmas Palabuhanratu. Hal ini menunjukkan bahwa terdapat perbedaan perilaku deteksi dini kanker serviks antara WUS wilayah perkotaan dengan wilayah pesisir.

\section{Karakteristik Responden}

Karakteristik responden pada penelitian ini dilihat dari umur, tingkat pendidikan, pekerjaan, dan pendapatan keluarga pada WUS yang ada di wilayah kerja Puskesmas Parungkuda dengan Palabuhanratu. Sebagian besar responden pada kedua wilayah kerja puskesmas berada pada rentang usia produktif, yang dimana merupakan saat yang tepat bagi WUS untuk melakukan deteksi dini sehingga kejadian kanker serviks mampu terdeteksi lebih awal dan penanganan lebih cepat dilakukan. Usia berhubungan dengan risiko terjadinya kanker serviks, dimana dengan bertambahnya umur meningkat pula risikonya. tingkat pendidikan di kedua daerah masih rendah. Tingkat pendidikan seseorang mempengaruhi perilaku mengenai kondisi kesehatannya. Seseorang dengan pendidikan yang lebih tinggi akan lebih mudah menerima informasi sehingga pengetahuannya lebih baik.(Wijaya D, 2010) Pendidikan merupakan salah satu faktor penting yang mendorong seseorang untuk lebih peduli dan termotivasi untuk meningkatkan derajat kesehatan dirinya dan keluarganya. Hal ini sejalan dengan teori bahwa pendidikan yang masih rendah merupakan salah satu penyebab rendahnya pemahaman masyarakat terhadap informasi kesehatan serta pembentukan perilaku sehat.(Wigati PW, 2016)
Sebagian besar WUS pada kedua daerah tidak bekerja atau sebagai lbu rumah tangga. Wanita yang tidak bekerja kemungkinan lebih sering di dalam rumah, dan hanya berinteraksi dengan orang sekitar rumah saja, sehingga informasi yang didapatkan kemungkinan terbatas. Hal ini menunjukkan WUS tidak dapat terpapar informasi lebih banyak tentang kanker serviks dibandingkan dengan ibu yang bekerja.(Yuliawati, 2012) Pendapatan keluarga pada sebagian besar responden berpenghasilan $\leq$ UMR Kabupaten Sukabumi dan dapat dikategorikan berpenghasilan rendah. Pendapatan keluarga yang kecil menyebabkan wanita lebih banyak memikirkan kebutuhan keluarga. Kesehatan tidak menjadi prioritas utama. Hal ini terkait dengan ketidakmampuan melakukan deteksi dini kanker serviks secara rutin karena relatif mahal, apalagi dengan jarak yang jauh dari pusat pelayanan kesehatan. Hal ini sejalan dengan Penelitian Melva (2008) yang menyatakan bahwa ada hubungan antara pendapatan keluarga dengan kanker serviks. Kanker serviks banyak terjadi pada keluarga yang berpenghasilan $\leq 1$ juta.(Melva, 2008)

Saat sel normal terpapar virus HPV, sel tersebut terinisiasi yang kemudian menjadi sel lesi prakanker, jika lesi prakanker ini terpapar lagi berbagai faktor risiko maka akan berubah menjadi kanker serviks. Terdapat banyak faktor risiko yang dapat memicu lesi prakanker menjadi kanker serviks. Dalam penelitian ini faktor risiko responden yang di kaji antara lain usia berhubungan seksual pertama kali, paritas, penggunaan kontrasepsi pil, dan jumlah pasangan seksual responden.

\section{Faktor Risiko Kanker Serviks}

Usia berhubungan seksual pertama kali $\leq$ 16 tahun lebih banyak ditemukan pada WUS di wilayah kerja Puskesmas Palabuhanratu dibandingkan dengan WUS di wilayah kerja Puskesmas Parungkuda. Secara uji statistik terdapat perbedaan yang bermakna. Hasil penelitian tersebut sejalan dengan data yang menyebutkan wanita yang menikah di usia kurang 
16 tahun lebih banyak ditemukan di pedesaan $(24,5 \%)$ dibandingkan di perkotaan (12,85\%). Data SDKI tahun 2007 menunjukkan wanita yang tinggal di desa yang menikah pada usia 15 tahun ke bawah mencapai $33 \%$ sedangkan di kota mencapai $14,3 \% .^{13}$ Daerah Palabuhanratu merupakan daerah pesisir Sukabumi yang dapat dikategorikan sebagai daerah pedesaan, dalam penelitian ini masih ditemukan wanita di daerah pesisir yang menikah di bawah usia 16 tahun. Usia pertama kali berhubungan seksual merupakan salah satu perilaku seksual yang dimasukkan ke dalam faktor risiko yang meningkatkan terjadinya kanker serviks.(Maine D, Hurlburt S, Greeson D, 2011; Emilia O, Kusumanto A, Freitag H, 2011; Boyle P, Levin B, 2008)

Pada variabel paritas sebagian besar WUS dengan paritas $\leq 3$ baik di wilayah kerja puskesmas Parungkuda maupun Palabuhanratu, dan untuk paritas $>3$ lebih banyak ditemukan di wilayah Palabuhanratu. Untuk hasil uji statistik didapatkan nilai $p=0,239$, hal ini menunjukkan tidak terdapat perbedaan paritas antara responden di wilayah kerja Puskesmas Parungkuda dengan Palabuhanratu. Hasil penelitian ini sejalan dengan penelitian Handayani di Karawang bahwa tidak terdapat perbedaan bermakna paritas pada wanita dengan IVA positif antara daerah pesisir dengan perkotaan dengan nilai $p=0,140$. (Handayani $\mathrm{Fl}$, 2015)

Kontrasepsi oral responden di kedua wilayah sebagian besar tidak menggunakan kontrasepsi oral dalam jangka waktu yang lama, persentase responden yang menggunakan kontrasepsi pil $>4$ tahun sebanyak 38,3\% (22 orang) terdapat di wilayah kerja Puskesmas Parungkuda. Dari hasil uji statistik melalui uji chisquare terdapat perbedaan secara bermakna pada variabel kontrasepsi oral responden antara wilayah kerja puskesmas Parungkuda dengan Palabuhanratu dengan nilai $p=0,02 \quad(p<0,05)$. Adanya perbedaan secara bermakna dengan persentasi terbanyak yang menggunakan kontrasepsi oral $>4$ tahun di wilayah kerja Puskesmas Parungkuda, hal ini berarti sesuai bahwa wilayah Parungkuda merupakan wilayah dengan kejadian kanker serviks yang tinggi salah satu faktor risikonya adalah penggunaan kontrasepsi pil jangka panjang $>4$ tahun.

Jumlah pasangan seksual responden pada kedua wilayah sebagian besar hanya 1 pasangan, dan untuk jumlah pasangan seksual $>1$ persentase terbesar yaitu $16,7 \%$ (10 orang) pada WUS yang berada di wilayah kerja Puskesmas Palabuhanratu dibandingkan dengan wilayah kerja Puskesmas
Parungkuda. Berdasarkan hasil uji statistik dengan uji chi-square didapatkan hasil perbedaan secara bermakna. Hasil penelitian ini sesuai dengan penelitian Susanti (2010) di Karawang, yang menemukan ada hubungan antara jumlah pasangan seksual dengan kejadian lesi prakanker $(p=<0,001)$. (Susanti l, 2010)

Berdasarkan hasil uji statistik untuk faktor risiko berhubungan seksual pertama kali $\leq 16$ tahun dan jumlah pasangan seksual $>1$ didapatkan perbedaan yang bermakna, namun terdapat ketidaksesuaian karena hal ini menunjukkan bahwa di Palabuhanratu kejadian kanker serviksnya rendah namun WUSnya lebih berisiko dibandingkan WUS di wilayah Parungkuda yang kejadian kanker serviksnya tinggi.

Beberapa teori menyebutkan bahwa wanita yang tinggal di wilayah pesisir lebih berisiko terhadap penularan penyakit seksual, dikarenakan biasanya di wilayah pesisir atau pelabuhan merupakan tempat singgah atau berhenti sementara para pelayar, namun untuk wilayah pesisir palabuhanratu yang berada di Kabupaten Sukabumi saat ini sudah beralih fungsi, bukan sebagai tempat yang banyak di kunjungi pengunjung yang menyebabkan penyakit menular seksual meningkat melainkan hanya sebagai tempat rekreasi keluarga. Sedangkan untuk wilayah Parungkuda yang merupakan wilayah perkotaan, memasuki era globalisasi ini perkembangan ekonomi, informasi dan pendidikan secara simultan akan mengarahkan kehidupan manusia pada format baru sebagai manusia modern yang dicirikan dengan cepatnya perubahan dan identitas tertentu. Terjadi benturan budaya karena pengaruh modernisasi sehingga menyebabkan perilaku masyarakat di wilayah perkotaan mengikuti perubahan tersebut, terutama dalam perilaku seksual maupun gaya hidup masyarakatnya. Hal itulah yang menyebabkan kenapa di Kabupaten Sukabumi kejadian kanker serviks lebih tinggi di wilayah perkotaan dibandingkan di wilayah pesisir.

\section{Perilaku (HBM) Penggunaan Skrining IVA}

Perbedaan perilaku deteksi dini kanker serviks berdasarkan teori HBM menunjukkan perbedaan secara bermakna pada variabel persepsi kerentanan dan isyarat untuk bertindak. Berdasarkan persepsi kerentanan maka individu yang memiliki persepsi kerentanan yang tinggi terhadap penyakit kanker serviks maka individu tersebut akan melakukan usaha untuk mencegah terjadinya penyakit kanker serviks salah satunya yaitu dengan melakukan tes IVA, (Guvenc G, Akyuz $A$, Acikel HC, 2011) karena di wilayah kerja 
Puskesmas Parungkuda responden memiliki persepsi kerentanan yang lebih tinggi, sehingga WUS yang melakukan pemeriksaan IVA cenderung lebih banyak dibandingkan dengan WUS di Palabuhanratu.

Hasil penelitian ini sesuai dengan hasil penelitian Wigati, bahwa keaktifan mencari informasi melalui teman, petugas kesehatan, penyuluhan, media cetak dan elektronik memengaruhi perilaku pelaksanaan tes IVA. Persepsi individu dari cues to action diharapkan mampu mendorong adopsi perilaku kesehatan jika individu sudah memegang keyakinan kunci lainnya mendukung tindakan. Motivasi kesehatan mengacu pada kestabilan perbedaan antara individu dalam nilai kesehatan dan kecenderungan untuk menjadi termotivasi dalam menjaga kesehatan. Individu dengan motivasi tinggi dalam menjaga kesehatan harus lebih mungkin untuk mengadopsi perilaku kesehatan yang relevan.(Wigati PW, 2016) adanya persepsi isyarat bertindak atau cue to action dalam metode tes IVA membuat individu atau WUS terdorong dalam melakukan tes tersebut. Hal ini dikarenakan informasi melalui teman, petugas kesehatan, penyuluhan, media cetak dan elektronik memengaruhi perilaku pelaksanaan skrining IVA.(Bakhtari AF, Nuri ZR, Sahebi L, 2012) Maka dari itu sosialisasi mengenai pentingnya deteksi dini kanker serviks perlu terus ditingkatkan guna meningkatkan perilaku deteksi dini kanker serviks dengan IVA di setiap wilayah.

\section{SIMPULAN}

Berdasarkan hasil penelitian terdapat perbedaan yang bermakna pada faktor risiko usia berhubungan seksual pertama kali, kontrasepsi pil, dan jumlah pasangan seksual, namun untuk faktor risiko usia berhubungan seksual $\leq 16$ tahun dan jumlah pasangan $>1$ terdapat di daerah yang rendah kejadian kanker serviksnya. Maka dapat disimpulkan bahwa walaupun dalam satu daerah WUSnya memiliki faktor risiko tetapi tidak bisa menentukan bahwa daerah tersebut akan tinggi kejadian kanker serviksnya. Pada perilaku deteksi dini kanker serviks berdasarkan teori HBM menunjukkan perbedaan bermakna pada variabel persepsi kerentanan dan isyarat untuk bertindak sehingga WUS di wilayah yang tinggi kejadian kanker serviksnya lebih banyak menjalani pemeriksaan IVA, namun walaupun di wilayah kerja Puskesmas Parungkuda lebih banyak yang menjalani pemeriksaan IVA belum mampu mendeteksi lebih awal penyakit kanker serviksnya.

\section{SARAN}

Hasil penelitian ini dapat menjadi dasar untuk penelitian selanjutnya dalam meneliti faktor risiko lain selain faktor risiko dari WUSnya itu sendiri, misalkan faktor risiko dari pasangannya. Bagi pemerintah setempat mampu meningkatkan sosialisasi mengenai informasi kanker serviks, baik terkait faktor risiko maupun deteksi dini dengan tes IVA.

\section{DAFTAR PUSTAKA}

Bakhtari Aqdam F, Nuri Zadeh R, Sahebi L. Effect of education based on Health Belief Model on Believe promotion and screening behaviours of breast cancer among women reffered to Tabriz health centers. Medl J Tabriz Uni Medl Sci. 2012;33:2531. In Persian, "n.d

Bensley RJ, Fisher JB. Community public health education methods: A practical guide. $4^{\text {th }}$ edition. Burlington, MA: Jones \& Barlet Learning, LCC.2009.

Boyle P, Levin B. World Cancer Report 20208 Lyon, France: IARC Press, International Agency for Research on Cancer;2008. $\mathrm{hlm}$. 418-23. (Diunduh tanggal 26 November 2017)

Dahlan S. Besar Sampel dan Cara Pengambilan Sampel: dalam penelitian kedokteran dan kesehatan. Edisi ke-3. Jakarta: Salemba Medika, 2013;1-20.

Dinkes Kabupaten Sukabumi. Laporan Penyakit Tidak Menular Tahun 2017. Sukabumi: 2017

Dirjen PP\&PL. Pedoman Teknis Pengendalian Kanker Payudara \& Kanker Leher Rahim. Kementrian Kesehatan RI Direktorat PP\&PL. 2010:1-3. 3. Health Technology Assessment Indonesia.

Emilia O, Kusumanto A, Freitag H. Bebas Ancaman Kanker Serviks. Jakarta: Media Pressindo;2010. hlm. 11-69.

Ferlay J, Soerjomataram I, Dikshit R, Eser S, Mathers $C$, Rebelo $M$, et al. Cancer incidence and mortality worldwide: sources, methods and major patterns in GLOBOCAN 2012. International journal of cancer. 2015;136(5).

Guvenc G, Akyuz A, Acikel HC. Health Belief Model Scale for Cervical Cancer and Pap Smear Test: psychometric testing. Journal of Advanced Nursing 67(2), 428-437. 2011.

Handayani FI, Perbandingan Karakteristik Dan Pengetahuan Tentang Kanker Serviks Pada Wanita Dengan Inspeksi Visual 
Asam Asetat (Iva) Positif Di Pesisir Dan Perkotaan. Karawang: Jurnal Kebidanan, Vol. VII; 01; 1-114, 2015. http : //www. journal.stikeseub.ac.id

Has DFS, Hendrati LY. Faktor Risiko Karakteristik dan Perilaku Seksual terhadap Kejadian Kanker Serviks. The Indonesian Journal of Public Health, Vol. 6, No. 1, Juli 2009: 38-43

IVA di wilayah Puskesmas Prembun Kabupaten Kebumen. Jakarta: Fakultas Kesehatan Masyarakat Universitas Indonesia; 2012.

Kemenkes RI. Pusat data dan informasi Kementerian Kesehatan RI. Jakarta:2015.

Kemenkes RI. Panduan Program Nasional Gerakan Pencegahan dan Deteksi Dini Kanker: Kanker serviks dan Kanker Payudara. Jakarta:2015.

Maine D, Hurlburt S, Greeson D. Cervical cancer prevention in the 21st century: cost is not the only issue. American Journal of Public Health. 2011;101(9):1549-55.

Melva. Faktor-faktor yang mempengaruhi kejadian kanker leher rahim pada penderita yang datang berobat di RSUP $\mathrm{H}$. Adam Malik Medan tahun 2008. Tesis, 2008.

National Programme For Prevention and Control of Cancer, Diabetes, Cardiovascular Disease and Stroke (NPCDCS). Available from: http://mohfw.nic.in/index1.php?lang=1\&lev el=3\&sublinkid=3627\&lid=2194

Satari M, Wirakusumah FF. Konsistensi Penelitian dalam bidang kesehatan. Bandung: Refika Aditama;2010;57-75.

Susanti I. Hubungan Usia Pertama Kali Berhubungan Seksual Dan Jumlah Pasangan Seksual Dengan Kejadian Lesi Pra Kanker Leher Rahim Pada Wanita Yang Melakukan Deteksi Dini Menggunakan Metode Inspeksi Visual Dengan Asam Asetat (Iva) Di Puskesmas Cikampek, Pedes Dan Kota Baru Kabupaten Karawang Tahun 2009 - 2010. Tesis. 2010.

Wigati PW. Analisis Jalur Dengan Health Belief Model Tentang Penggunaan Skrining Inspeksi Visual Asam Asetat Untuk Deteksi Dini Kanker Serviks Pada Wanita Usia Subur Di Kota Kediri. Tesis. Surakarta:2016. Gao W, Paterson J, DeSouza R, Lu T. Demographic predictors of cervical cancer screening in Chinese women in New Zealand. N Z Med J.2008;121;(1277):8-17.

Wijaya D. Pembunuh Ganas itu bernama kanker serviks. Yogyakarta: Sinar Kejora;2010.

Yuliawati. Faktor-faktor yang berhubungan dengan perilaku WUS dalam deteksi dini kanker leher rahim metode 